\title{
Correspondence
}

Journal of Medical Genetics, 1977, 14, 387-388

\section{Chromosome survey of total population of mentally subnormal in North-East Scotland}

SIR,

I read with interest the paper by Speed et al. (1976). It provides much needed baseline data on the prevalence of chromosomal abnormalities in a defined population, as opposed to a selective hospital population. This is important since studies will shortly be required to assess the effectiveness of genetic counselling and prenatal diagnosis programmes in reducing the prevalence of chromosomal abormalities. This emphasis on prevalence is because the planning of caring services for the mentally handicapped is primarily based on prevalence data not incidence in the newborn.

It would also have been interesting to see the prevalence rates presented as a proportion of the appropriate age category of the total population of the region in addition to being expressed as a proportion of the mentally handicapped. The reason for this is that comparisons with different areas of the country would then be easier and more accurate since the criteria for entry to other mental handicap registers may differ. In particular, the determinants for the inclusion of the mildly mentally handicapped may be quite difficult to make.

I should, however, like to comment on the comparison made between the incidence of chromosomal anomalies in the Edinburgh newborn population (Jacobs et al., 1974) and the prevalence in the mentally handicapped population of North East Scotland (Table IX, Speed et al., 1976). I would suggest that the comparison is suspect since the incidence of a condition at birth ought to be compared with a later age specific incidence but not with prevalence.

\section{P. ForsTER.}

Department of Community Medicine University of Sheffield Medical School Beech Hill Road, Sheffield

\section{References}

Jacobs, P. A., Melville, M., Ratcliffe, S., Keay, A. J., and Syme, J. (1974). A cytogenetic survey of 11,680 newborn infants. Annals of Human Genetics, 37, 359-376.

Speed, R. M., Johnston, A. W., and Evans, H. J. (1976). Chromosome survey of total population of mentally subnormal in North East of Scotland. Iournal of Medical Genetics, 13, 295-306.

This letter was shown to Dr. Speed who comments as follows:

As Dr. Forster emphasised, the purpose of our survey was to obtain much needed baseline data on the mentally subnormal in a total population. However, our study was not confined to prevalence of chromosome abnormalities in the retarded, but included many other aspects covered by a range of detailed epidemiological data. These are being prepared for publication, but we present in the Table the prevalence ratio related to the age distribution. This was not included originally because of chance variation for rates calculated on small numbers.

Since constitutional chromosome abnormalities are either transmitted via the germ cells or arise during the very early mitotic divisions following

Table Chromosome abnormalities rates per 100000 population

\begin{tabular}{|c|c|c|c|c|c|c|}
\hline \multirow[t]{2}{*}{ Age (y) } & \multicolumn{2}{|c|}{ Down's syndrome } & \multirow{2}{*}{$\begin{array}{l}\text { Other autosomal } \\
\text { abnormalities } \\
\text { (both sexes) }\end{array}$} & \multicolumn{2}{|c|}{ Sex chromosome abnormalities } & \multirow{2}{*}{$\begin{array}{l}\text { Total chromosome } \\
\text { abnormalities }\end{array}$} \\
\hline & Males & Females & & Male & Female & \\
\hline $0-4$ & $67 \cdot 74$ & $49 \cdot 8$ & $8 \cdot 0$ & - & - & $67 \cdot 1$ \\
\hline 4-9 & $79 \cdot 3$ & $79 \cdot 0$ & $2 \cdot 6$ & $14 \cdot 9$ & - & $89 \cdot 3$ \\
\hline $10-14$ & $134 \cdot 7$ & $44 \cdot 0$ & $5 \cdot 3$ & $15 \cdot 5$ & - & $104 \cdot 1$ \\
\hline $15-24$ & $108 \cdot 8$ & $91 \cdot 4$ & $4 \cdot 1$ & $21 \cdot 8$ & $2 \cdot 8$ & $116 \cdot 6$ \\
\hline $25-34$ & $96 \cdot 4$ & $58 \cdot 1$ & $5 \cdot 5$ & $11 \cdot 1$ & $3 \cdot 6$ & $89 \cdot 9$ \\
\hline $35-44$ & $66 \cdot 1$ & $27 \cdot 9$ & 3.6 & $7 \cdot 3$ & $3 \cdot 5$ & $55 \cdot 4$ \\
\hline $45-54$ & $34 \cdot 3$ & $24 \cdot 2$ & - & $7 \cdot 6$ & $3 \cdot 5$ & $34 \cdot 5$ \\
\hline $55-64$ & $15 \cdot 4$ & $3 \cdot 3$ & 1.8 & $7 \cdot 7$ & - & $14 \cdot 2$ \\
\hline 65 and over & $3 \cdot 8$ & - & $1 \cdot 5$ & $7 \cdot 7$ & $4 \cdot 9$ & $9 \cdot 0$ \\
\hline All ages & $67 \cdot 1$ & $39 \cdot 2$ & $5 \cdot 3$ & $11 \cdot 0$ & $2 \cdot 4$ & $62 \cdot 5$ \\
\hline
\end{tabular}


fertilisation, the data from the Edinburgh study of their incidence in consecutive live newborn give a reference baseline which may be contrasted with prevalence data from any other defined age group. Of course, certain of the constitutional chromosome anomalies are well known to be associated with a high infant mortality, but for certain conditions not known to be associated with high mortality (e.g. Klinefelter's syndrome), one might expect that the proportion in the population would remain fairly constant for all age groups. For other conditions (e.g. Down's syndrome) mortality will result in decreased proportions as age advances. The com- parison of the Edinburgh birth study with our own was simply intended to show that there was an: increased proportion of both autosomal and sex $\overrightarrow{\bar{F}}$ chromosome abnormalities in the mentally retarded section of the general population. It was considered worth while to attempt an estimate of the liability to $\overline{\bar{N}}$ mental retardation and to indicate that the risk was greater for some syndromes than others.

R. M. SPeEd, A. W. Johnston, H. J. Evans, AND G. INNES.

MRC Clinical and Population Cytogenetics Unit, Western General Hospital, Crewe Road, Edinburgh 